\title{
STAGES AND AREAS OF THE USE OF IT TOOLS SUPPORTING THE MANAGEMENT OF IT PROJECTS
}

\author{
Jolanta Pondel \\ WSB University in Wroclaw, Wrocław, Poland \\ e-mail: jolanta.pondel@wsb.wroclaw.pl
}

\author{
Maciej Pondel \\ Wrocław University of Economics, Wrocław, Poland \\ e-mail: maciej.pondel@ue.wroc.pl \\ (C) 2018 Jolanta Pondel, Maciej Pondel \\ This is an open access article distributed under the Creative Commons Attribution-NonCommercial-NoDerivs license \\ (http://creativecommons.org/licenses/by-nc-nd/3.0/) \\ DOI: $10.15611 / \mathrm{ms} .2018 .1 .06$ \\ JEL Classification: M1, M2, O3
}

\begin{abstract}
Conducting informatic projects requires the application of modern solutions that streamline workflow. Current projects are becoming more complicated, during their implementation, large amounts of data and information are generated. In addition, in many external sources we can find data and information of the various forms and levels of detail. To get from this data a valuable knowledge, it is necessary to use new data analysis techniques and new technological solutions. The article sets out to present a dissertation of considerations for IT projects and the steps of IT project were highlighted with areas and IT tools that support their implementation. The aim of this article is to assess the current level of use of IT tools by the companies considered as leaders, at various stages of IT projects implementation. The authors also rated the intensity of IT tools usage in various areas of project execution. The paper includes results of research conducted, and can serve as a guideline for enterprises developing IT tools intended to streamline informatic projects. The contents of the dissertation are based on literature studies and empirical research.
\end{abstract}

Keywords: IT project, stages of the project, IT tools, management areas.

\section{Introduction}

The project-oriented approach to implementing changes in business has been recently gaining in importance. All that is related to the subject of projects, e.g. task execution, cost analysis, schedule development, team building, project initiating and execution, etc. depends on changes on the market and the resulting changes in enterprises. Until recently, businesses managed without informatic tools and systems supporting decisionmaking. Whether a given operation undertaken by an organisation was effective or not stemmed primarily from the quality of the decisions made by them. These, however, were often accidental and unrooted in the thorough analyses of the available data and information. Decisions were based on experience, knowledge of the market or line of business, or other, not always fully defined factors, where the manager's intuition and stroke of luck were most important.

Nowadays, it is difficult to name an enterprise which has effectively conducted its business operation for a long period of time without applying an IT system supporting decision-making. This mainly stems from the need to minimise risk in decision-making processes, which requires a thorough analysis of the available information. Information is the key success factor. None the less, the amount, form, and diversity of data and information available to businesses become a problem.

Based on research results ${ }^{1}$ (cf. [Computerworld 2015]), it can be stated that in 2015, Business

${ }^{1}$ Survey-based study conducted in 2015, survey sample: 111 enterprises of different sizes, coming from various lines of business, which apply IT tools (research task "IT tools supporting project management in enterprises", implemented under a special purpose grant). 
Intelligence class systems were used by $78 \%$ of leaders in their respective lines of business operating in Poland, and $70 \%$ of companies which were/are some of the most important business entities in their markets. For comparison, among enterprises which have not implemented an analytical system, as many as $57 \%$ did not belong to the group of key players in their respective market sectors. Therefore, it can be said that (particularly BI class) informatic systems are an important tool applied to build a long-lasting competitive advantage.

Taking into consideration the following, we will present the specifics of IT projects, their construction (stages in the most popular methodologies), and areas that are supported by the use of information systems. Next the authors present the results of the research, which identifies the stages and areas where advanced IT companies (leaders of IT project) most often use IT tools.

This will help to recommend to the companies less advanced (outside of the ranking list) how they can make their projects more efficient. This regards the intensity of the IT tools usage, the stages of projects, and the areas in which the quality of their activities can be improved by the use of adequate/ similar actions like more advanced companies.

\section{Enterprises' activities}

To be competitive and attain specific commercial results, companies operating on the market must quickly analyse market conditions, adjust their business models to the market situation, and deliver products/services meeting customers' expectations. This seemingly simple condition of competitiveness requires the application of specific methods and tools which considerably streamline making efficient decisions and recognising customer needs, while improving the effectiveness of production and delivery as well as supporting the sale of products and their subsequent servicing, etc. Competitiveness contributes to generating innovation, primarily in sectors such as IT, telecommunications and transport.

When attaining the goals they set for themselves, organisations undertake activities which can be divided into categories with respect to repetitiveness and delivery complexity [Trocki, Grucza, Ogonek 2003] (Figure 1), i.e.:

- routine,

- improvised,

- process-based,

- project-oriented.

Given the effectiveness of company management as well as the attainment of goals and tasks, the most significant function is that of defining repetitiveness and the complexity of tasks set out.

Routine operations performed in an organisation are all types of activities which are not excessively complicated and characterised by low complexity (e.g. invoicing) and high repetitiveness. Performing such activities is easy as they occur quite frequently. They are usually carried out rapidly and without the need for additional activities which would condition their attainment.

Improvised activities in an organisation are characterised by low or (often) no repetitiveness

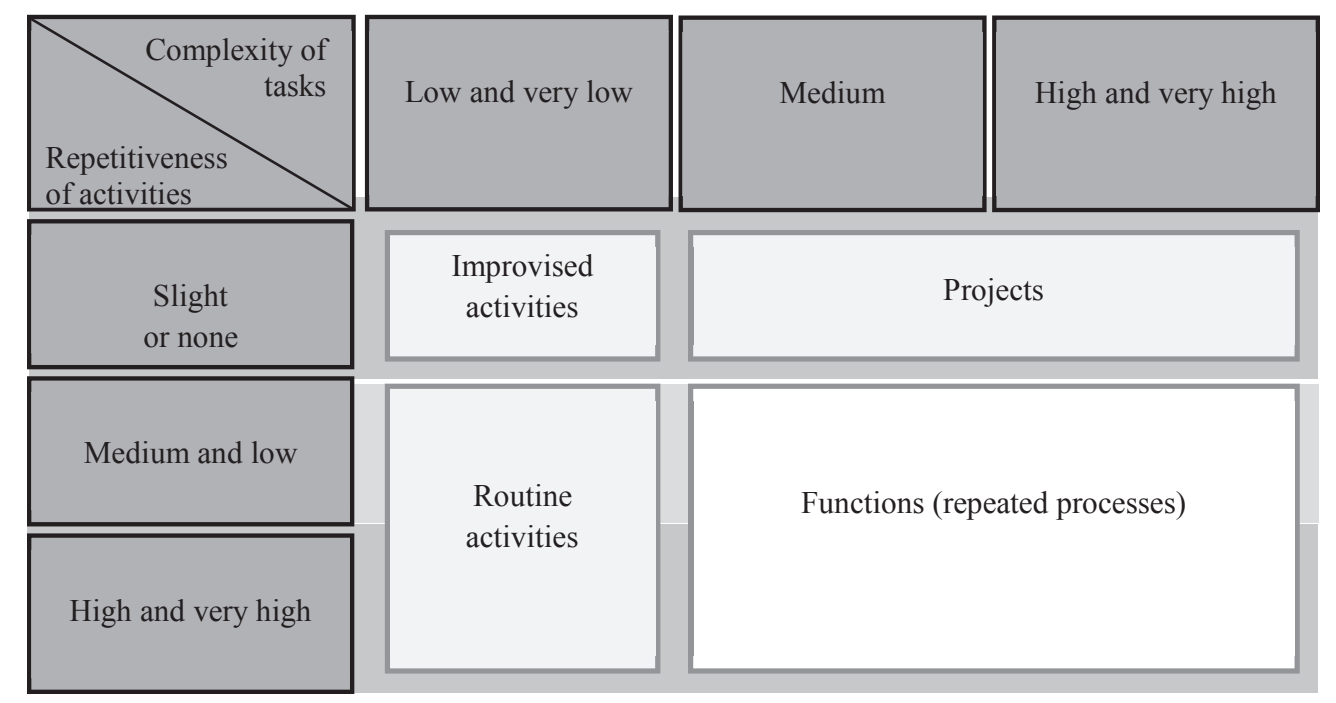

Fig. 1. Classification of activities in an enterprise

Source: own study based on [Trocki, Grucza, Ogonek 2003]. 
and low complexity of the tasks involved. These are occasional activities, a good example of which is the need to draw up a reply to a formal letter which requires non-standard and untypical activities.

A higher degree of repetitiveness and complexity is a characteristic of activities referred to as processes (performing specific functions). To execute them, enterprises apply plans and procedures arranged beforehand. The results of these activities are usually subject to diverse analyses, constituting a basis for the development/improvement of procedures used in the organisation, a good example of which can be a customer support system enabling claims.

The last group of activities shown in Figure 1 is projects. These activities are characterised by limited repetitiveness (most often none) but at the same time a very significant degree of complexity. Usually, these are activities related to new (not repeated) operations, tasks and solutions which must be undertaken with respect to an occurring/specific situation, problem or a customer's new requirements. To perform an activity of this type, one must determine many mutually dependent conditions (Figure 2). Most often, an author/manager/owner, responsible for task delivery, is appointed to perform a project-oriented activity. Project-oriented activities are burdened with a high degree of risk and a large amount of information to be collected and processed so that the task set out can be attained [Kerzner 2013].

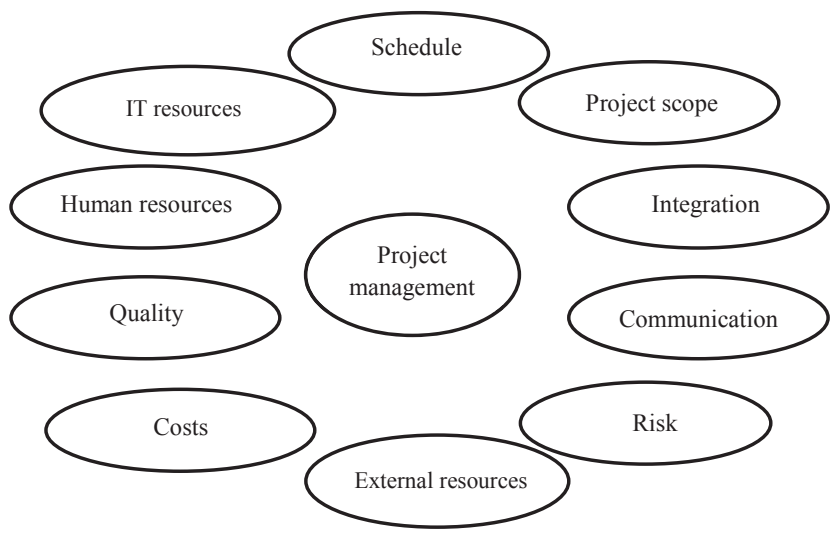

Fig. 2. Key factors of project management

Source: own study based on [Duncan 1996].

Project management consists in applying available knowledge, skills, tools, and techniques to perform skills activities aiming to meet or exceed the project ordering party's requirements and expectations [Duncan 1996].

\section{Specificity of informatic projects}

An extremely interesting project category (with a low degree of repeatability and a very high degree of complexity) are IT projects. IT system are increasingly often used to optimise certain business processes (e.g. workflow implementation), being a basis of products/services offered (e.g. SaaS model based software) and even determining the efficiency of the business model chosen by the organisation (Uber, Netflix or Airbnb). The aim of an IT project is usually to develop an informatic solution (system) with defined sets of correlated elements, i.e. equipment, software, human and financial resources, as well as organisational and information-based structures and elements [Schwalbe 2015]. The outcome of an IT project is the development of a unique product. As a result, the work methodology behind every project of this type should be considered to be innovative and creative. To process data using computer technology is a fundamental function of a solution developed in such a manner. IT systems are usually understood to be systems supporting the operation of enterprises, particularly as far as decision-making is concerned ${ }^{2}$.

The complexity of informatic projects should be considered as pertaining to their [Pawlak 2006; Szyjewski 2004]:

- Interdisciplinarity - delivery of IT projects very often requires the involvement of knowledge of various fields, which may cause organisation and communication problems.

- Comprehensiveness - delivery of IT projects encompasses the whole of activities indispensable for their completion (planning, preparation, implementation, testing, evaluation, and further development).

- Diversity of resources used - delivery of IT projects requires financial and tangible (equipment and premises), as well as intangible resources (knowledge and information). The fact that these resources are usually limited and not always available, or that they have various forms and sources, is an additional impediment. Moreover, these are very often hidden resources.

Also, it should be pointed out that the delivery of IT projects means activities undertaken within a specific time-frame and budget. These are very important parameters affecting the effectiveness of project execution and its success (success understood as a project of a specific quality delivered within a specific time, but - first and foremost - one ensuring the assumed value to its recipient). In the case of IT

\footnotetext{
${ }^{2}$ An IT system contains such software (in particular the currently popular utility software using the Internet).
} 
projects, the increase in the size of a project does not lead to a decrease in its unit cost. The cost of the project grows non-linearly (there are no economies of scale) [Szyjewski 2004].

Every informatic project is usually non-standard, and therefore implementation solutions are specific for every organization, so every IT project should be considered to be a unique one. While the experience gained over the course of a given IT project cannot be directly repeated when dealing with another one in the form of, for instance, the same activities, it becomes a significant support in forecasting and making decisions related to the delivery of further projects. The uniqueness of every project is in a way a constraint, forcing one, as it were, to apply a creative and innovative approach to every new project and problems However, the fact that every project is exceptional does not only concern the method of its execution but also the product or service which comes into being as a result [Duncan 1996]. The activities involved in a project, as well as its results, are unique but also uncertain in terms of their final shape. The uncertainty and the resulting risk that pertains to the final shape of a project usually decrease over the course of work and with consecutive approvals of project stages [Lock 2009; Pawlak 2006; Meredith, Mantel Jr 2011].

Taking all this into consideration, the important role of the project manager (PM) must be highlighted. The project manager is the person responsible for the delivery of their project - its success or failure. Managing IT projects is rightly considered to be one of the most responsible tasks; organisations intent on effectively performing tasks related to projects employ specially trained people who know new IT solutions, considerably streamlining the performance of such activities.

Both tangible and intangible factors considerably affect enterprises' competitiveness, particularly those running IT projects characterised by high complexity and a low degree of repetitiveness. Investing in modern informatic tools brings evident benefits, and negligence thereof is obviously reflected by business results. Attaining a competitive advantage by IT companies depends to a great degree on the company's intangible components - information, expertise, and tools which the enable effective use and management of these assets.

The execution of projects, particularly those IT-oriented, is difficult due to the very rare and often non-repetitive activities involved in them and their considerable complexity; an additional factor is the fact that they are conducted in unstable market conditions with frequently changing client's requirements. Having decided to undertake a project, an enterprise becomes involved in new areas of knowledge and tackles new tasks, which is why it is very important that companies appropriately define and organise the scope, timeframe and methods of work. What becomes exceptionally important is the process of selecting the proper methodologies in the area of the execution of project works and control of the project stages, which enables efficient project delivery thus ensuring the attainment of goals, i.e. the results for which the project was undertaken.

Project management involves developing a concept, indicating activities indispensable for its execution, planning, performing the planned activities, as well as controlling and correcting them [Koźmiński, Piotrowski 2013].

The selection of an appropriate, i.e. effective, method of project management becomes an important issue. The methodology chosen for the execution of a specific project should be adjusted to its aspects such as the type of project, number of activities planned, as well as its size and difficulty, allowing for the cost of its implementation, and also the feasibility of all assumed project goals and results. There are numerous methodologies and the selection of the right one depends on many factors. In practice, two approaches to project management can be identified: the traditional approach and the agile one.

As far as the traditional approach is concerned, the sequences of steps to be taken as part of the project are identified. Here, a project can be divided into many phases, also referred to as stages: stages of initiation and planning, and stages related to project execution and monitoring. The set of stages/phases is also called the project life cycle, which is specific to particular organisations or project types. An example may be the PRINCE2 [PRINCE2 2006] and PMBoK [PMI 2013] methodology.

However, taking into account the pace at which markets are growing, one can observe increasingly frequent changes in the attitude to the traditional project management methods, primarily as far as the approach to IT projects is concerned. Changes to market conditions, situations where not all of the client's requirements are defined or clearly defined, or the client's requirements changing during project execution, resulted in the application of the socalled agile approach. According to this approach, the project is seen as a set of relatively small tasks (steps), whose scope can change all the time so that the client's needs are best catered for. The result is the introduction and application of the so-called nontraditional project management styles, Agile and Extreme project management [Kerzner 2013]. 
The applied project management methodologies (both traditional and non-traditional ones) make it easier to maintain the right balance between elements which must be taken into account - from setting goals all the way through to planning, organising, motivating to control and coordination. They concern functional issues related to the planned course of the project, institutional issues pertaining to appropriate project organisation, and personal issues linked with human behaviour, which should be considered about in every undertaking.

It is difficult to indicate which of these methodologies is most effective, as each of them has its distinctive characteristics. Agile methodologies, allowing the attainment of the assumed goal by small steps, are being more and more frequently applied for the purposes of IT projects. Nevertheless, it should be noted that particular stages (indicated in the context of traditional methodologies) of project execution (initiating, planning, execution, control and monitoring, closing) are present in agilemethodologies. Irrespective of the distinctive characteristics and differences between methodologies, each should lead to the maximally effective attainment of the project goal, which means supporting the project management process over its entire course.

It is important to know that while IT projects are difficult to implement and costly, their final effects (IT systems) contribute to cost reduction, increase profitability and, in particular, open up new opportunities for companies to grow and be competitive [Cleland, Ireland 2006] and regardless of the chosen methodology of IT project implementation, IT tools are needed.

\section{Stages and areas of the IT project and the support classes of IT tools}

Nowadays, the amount of information which an enterprise should analyse to rationally run its business operations is so large that without the application of IT tools making an effective decision would be at least difficult and burdened with a very high level of risk. According to an IBM report, 2.5 trillion bytes of data of different kinds are generated every day $[\text { IBM 2016] }]^{3}$. This large amount of information being generated is a global phenomenon concerning entities operating in various lines of business and markets. As a result of the rise in the amount of global digital data, the conventional data processing and storage technologies have become inapplicable to the current needs.

In a study conducted by Microsoft in 2016, ${ }^{4}$ $80 \%$ of owners and managers operating in the sector of small and medium-sized businesses admit that investment in IT tools supports optimisation of business processes [Jamrogiewicz 2016]. However, half of them did not develop a plan for the digital transformation of their business, and most of the organisations surveyed do not plan to hire a person specialising in data analysis. It is important, none the less, that among the key investment areas company owners indicated their willingness to improve IT security, ensure tools for more effective customer service, and streamline communication between staff members. Among the enterprises surveyed, as many as 37 per cent confirm that they have a plan to introduce digital tools and improve their competitiveness by digitalising processes, which is a very positive phenomenon.

Taking the above data into account, it becomes very important to identify the areas of IT project streamlining, as thanks to the applications developed employees and heads of enterprises can much more efficiently perform their tasks, achieve their goals, and create value for their clients.

There are many IT tools on the market which can be useful in the process of managing informatic projects. Also, there are numerous project management methods, but one of the most frequently used ones was developed by the Project Management Institute (PMI) and called PMBOK (Project Management Body of Knowledge). The methodology involves five stages pertaining to project execution. These are [Philips 2011; Schwalbe 2015]:

- Initiating - the stage of defining a new IT project or a new phase of an existing project by obtaining indispensable authorisation from the project sponsor to enable the start of the project or phase, and another stage of the IT project.

- Planning - the stage which involves establishing the scope of the project, refining the objectives, and defining the course of action required to attain the objectives. What must be taken into account at this stage is the scope of the project, its timeframe and costs, as well as issued related to quality, risk and communication.

- Executing - the stage consisting in performing the work defined in the project management plan to satisfy the project specifications and assumptions.

\footnotetext{
${ }^{3}$ Here, the amount of semi-structural data (e.g. XML files with relevant XML Schema files) prevails by far, along with almost structural (e.g. web clicks streams) and non-structural data (e.g. text files, PDF's, images and videos).

${ }^{4}$ Microsoft's annual survey called "Modern IT in MSB's 2016" and conducted by the research company Ipsos MORI.
} 
At this stage, actions are undertaken to ensure the appropriate quality of the end product and the whole execution process. The project team management is a very important and difficult aspect of this stage.

- Monitoring and controlling - the stage consisting in reviewing, tracking and regulating the course and outcomes of the project. At this stage, areas must be identified where there are deviations from the plan and changes must be initiated. What must be paid particular attention to is costs, project schedule, and quality. Also, borne in mind must be all sorts of risk that may arise. Controlling an IT project consists in, first and foremost, comparing the current state with the previously developed plan and taking measures aiming to minimise potential deviations. Monitoring an IT project involves recording progress as well as analysing the pace of work and the course of the project.

- Closing - the final stage, stemming from the previous ones. It consists in finishing actions in all process groups and formally closing the project, or - if the project is executed in phases - a phase thereof. It is worth preparing, systematising and completing the project documentation and thinking about what conclusions can be drawn from the project execution so that they can be used when undertaking a new IT project (learning and optimisation of the organisation of IT project management).

For the correct design of IT solution development processes, it is necessary to indicate areas where data and information will be collected and then processed. It is important for the success of informatic projects to establish at the very beginning its components, including system users, decision-makers, project stakeholders, scope of data and information to be processed, available and necessary resources, acquisition and processing tools, etc., as well as sets of models indispensable for data and information processing.

Having at one's disposal information, appropriate in terms of quality and quantity, related to new IT solutions, sources of the acquisition and the processing (use) of information to be used by the project manager, and the entire team, is a key element, one conditioning the success of the whole project, as it decreases the risk inherent in the actions taken. When selecting IT tools to streamline project execution, one must take into account the project's key areas. The currently available systems supporting IT project management cover all key areas of the acquisition, processing, and delivery of information. These include:

- integration of the company's internal data/ information - integration of data/information related to organisational aspects, impacts on the project environment, processes, as well as the company's products and services,

- integration of project stakeholders - allowing for the structure and relations of the participants in the whole project process,

- support of knowledge transfer - efficient transfer of knowledge within the organisation and between other (external) participants in the project,

- modelling and simulation of events which could take place during the stages of initiating, planning, executing, controlling and closing of the IT project.

It becomes indispensable to apply specific IT tools in each of the said areas for the purpose of their correct handling. As a result of the growing possibilities of computer technologies, IT tools are being applied on an increasingly large scale at each stage of IT projects (which has been verified by research ${ }^{5}$ ). Conducting IT projects requires the application of technologies for collecting and analysing large volumes of complex data. The data can originate from traditional databases, e.g. used by organisations and containing so-called internal data or from other sources (documents, e-mail messages, blogs, and social media). Data available in these sources may come in many shapes (structures) - both definite and indefinite, which makes it difficult to distribute and process it with the available IT infrastructure (analytical architecture and tools) and computation methods. Consequently, new informatic tools are being developed to facilitate the exploration of this diverse data.

The classes of IT tools supporting various stages and areas of project management can be distinguished [Bernroider, Ivanov 2011; Schwalbe 2015; Wiki 2016; Pondel, Pondel 2016]:

- Project portfolio management - software enabling synchronisation and management of multiple projects executed simultaneously in an organisation. The purpose of project portfolio management is to optimise the use of resources and schedule projects so to ensure that they are as effective as this is only possible through achieving a maximum number of strategic goals with the assumed resource usage level.

- Planning - a process comprising organisation, control and optimisation of workload over the

\footnotetext{
${ }^{5}$ Survey-based study conducted in 2016, survey sample: 111 enterprises of different sizes, hailing from various lines of business, which apply IT tools.
} 
course of an IT project. Software designed for this purpose should make it possible for the user to develop a plan for the project, assign resources to tasks, track progress, manage the budget, and analyse workloads. One of the most common ways of imaging this data is a visualisation of a project plan as a Gantt graph. The Gantt graph shows activities as a bar chart where the bars represent the execution times of particular tasks.

- Resource management - comprises tasks related to indicating, evaluating and allocating the resources indispensable for the delivery of an IT project. It concerns both the internal and the external resources of the enterprise, indispensable in the process of the execution of consecutive project stages. Software supporting resource management enables the storage of a repository of resources and automation of the said processes.

- Document management - enables tracking, developing and storing documents used over the course of the execution of all IT project stages. The software should offer the user the possibility of drawing up and editing documents as well as sharing them with people taking part in the project (access with various authorisation levels) through appropriately designed navigation and search mechanisms.

- Incident management - a functionality also known as ticket systems - enabling receiving, classifying and delegating reports in an organised manner. Such systems streamline solving reported problems. Problems may arise at every stage of the project, but this functionality is most often used during project execution and delivery. This kind of software is mainly responsible for [Rawski 2016]:

- collecting reports of errors, incidents, and faults in the form of so-called tickets, which contain references to the task or resource which they concern. They must contain a detailed description and gather supporting materials (files, screenshots, etc.),

- classifying errors and faults and giving them priorities, as well as suggesting execution times,

- sending reports to the relevant people (responsible for their analysis and, if necessary, rectification),

- handling internal communication with respect to tickets,

- monitoring report statuses and tracking the history of their execution,

- reporting.
- Workflow management - enables the effective management of the course of business processes. The software is a supporting tool, facilitating organisation and the streamlining of work over the course of an IT project at each of its stages. Tasks and documents can be indicated that describe consecutive stages of the process, indispensable for attaining a specific business goal. [Schmidt 1998; Demeyer et al. 2010]. This optimises the results of the entire team's work by facilitating the circulation of documents between the project team members and provides an opportunity for the electronic management of multiple business processes indispensable for project execution, e.g. delegating tasks to be performed or registering documents.

- Supporting cooperation - consists in enabling cooperation of groups working on similar or the same tasks, constituting teams responsible for the execution of common tasks (project teams). The software of this kind helps people involved in common tasks achieve goals by streamlining their communication. Good examples of that are using e-mail, calendar, text messaging, wiki and tabs, or the increasingly common social media (such as Yammer, Slack, Twitter and Facebook).

- Business analytics - a combination of various tools, software, and expertise delivered as solutions enabling the better, more efficient prediction and shaping of business goals by decreasing the risk of decisions. These solutions enable detecting and analysing trends, patterns and anomalies and can be used at each stage of an IT project.

When working on informatic projects (regardless of their number and size) it is worth applying the available software facilitating project management. This helps to improve the effectiveness of the work of the entire team involved in the project. Applications supporting the development and management of projects streamline areas including cooperation, facilitate scheduling, task management and developing reports, enable communication within teams, as well as making it possible to inform clients about the course of project works on an on-going basis. IT tools designed to run projects not only help keep them in order but also increase the likelihood of the planned activities being completed on time.

The following section of the paper will present the results of research on the verification of the use of IT tools in the implementation of IT projects by companies of various industries. 


\section{The practice of tool application (survey)}

Collecting and keeping data and information is now sufficient for enterprises to be able to efficiently execute their operations. It is important to introduce proper procedures for the delivery and analysis of information in the most effective and appropriate manner possible so that they satisfy decision-makers' business needs, which is crucial when dealing with some of the organisation's most complex operations, i.e. projects. Enterprises are more and more efficiently applying IT tools to perform their operations, so systems supporting projects should be useful and result in optimisation and streamlining of all areas related to the management and execution of projects.

There are many solutions available on the market that can be applied in the above-mentioned areas supporting IT project management. In the context of the previous deliberations regarding the described areas and organisations' use of IT tools, an empirical study was conducted aiming to obtain information about the intensity of the application of IT tools for specific stages of informatic projects. Enterprises coming from various sectors participated in the survey.

The issue is interesting, as it transpired from a study conducted in $2015^{6}$ that the application of IT solutions in businesses, despite not directly causing an increase in their competitiveness on the market, definitely impacts on their operations resulting in improving their effectiveness and contributing to a better quality of their relationships with clients. The introduction of an IT solution influenced to the highest extent the area of making better/more appropriate business decisions $(54 \%)$, then the improvement of project plans (48\%), improvement of the quality and consistency of data related to projects $(46 \%)$, improvement of the "transparency" of activities $(44 \%)$, monitoring of project processes (39\%), improvement of relations with the client $(36 \%)$, ensuring data integrity and decrease in project risks (33\%), and broadening the scope and quantity of data for making complex decisions (31\%). The lowest rated area was an increase in the organisation's competitiveness after the introduction of an IT system for project management $(28 \%)^{7}$.

The results are presented in Figure 3.

The goal of the survey conducted in 2016 was to obtain information related to the extent of the use of IT tools at particular project stages as well as to identify and assess areas of the use of IT tools for IT project management. The respondents were asked to indicate and evaluate the IT tools used in their IT projects.

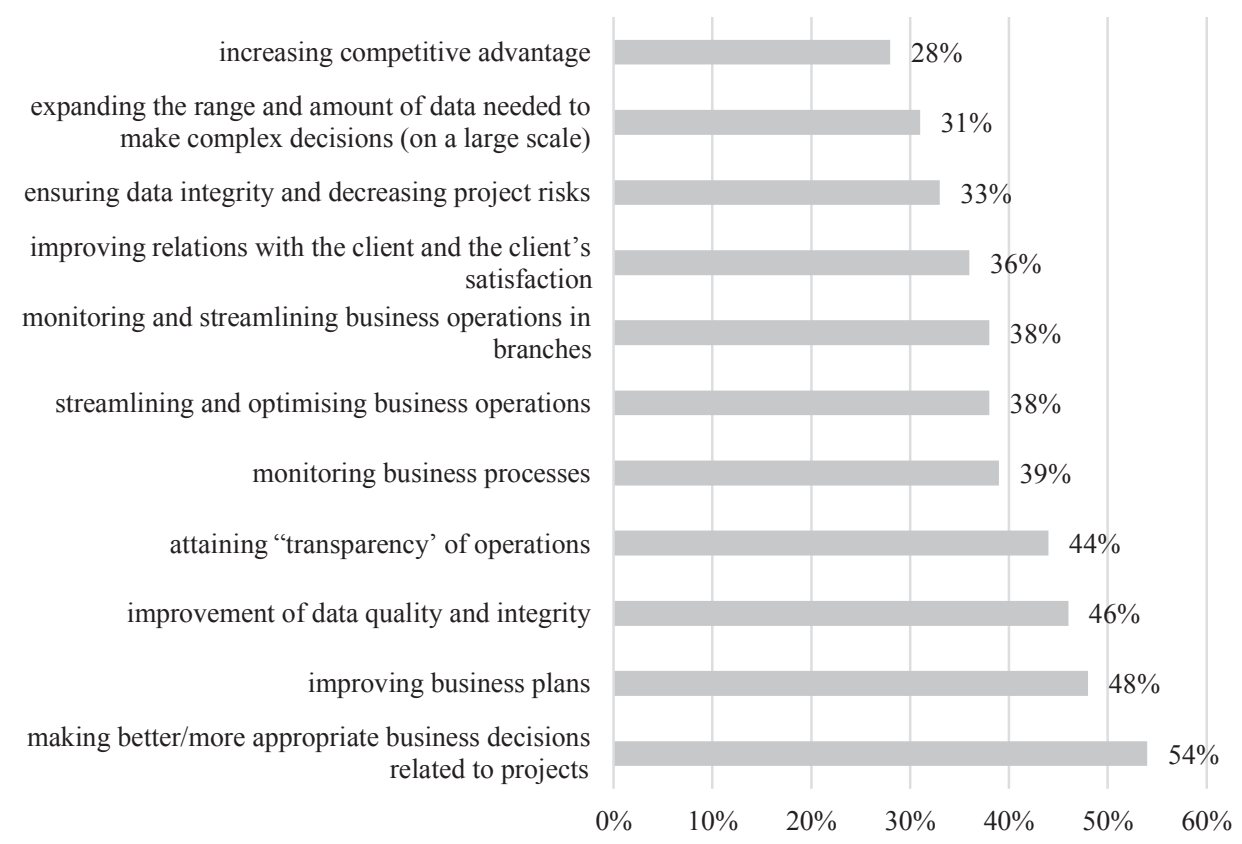

Fig. 3. Increase in the extent of operational streamlining in enterprises following implementation of an IT solution Source: own study based on original survey results.

\footnotetext{
${ }^{6}$ Survey-based study conducted in 2015, survey sample: 111 enterprises of different sizes from various lines of business which apply IT tools.

${ }^{7}$ In all likelihood it stemmed from the fact that an enterprise's competitiveness is influenced by a great deal of factors.
} 
The scope of the survey included 109 enterprises from various lines of business, selected on the basis of rankings published in the "Rzeczpospolita" and "Puls Biznesu" newspapers where they declared running IT projects. The selection of companies was deliberate because they are companies that have achieved market success and their approach to operations, the tools used can be a model for less advanced companies.

The sectoral coverage of the surveyed companies showed that the IT sector was the most represented ( $29 \%$ of all enterprises). Tourism, catering, hotel and entertainment companies accounted for $19 \%$, while those in the finance industry (including banking and insurance) accounted for $11 \%$. Another group was the energy/water/energy companies and they accounted for $8 \%$. Education, distribution and trade represented $6 \%$ of respondents, while auditing/consulting and telecommunications accounted for 5\% of all respondents. Public administration and uniformed services were a group of $5 \%$ of respondents. The least numerous groups were transport, logistics $(3 \%)$, health/pharmacy (2\%) and real estate/construction $(2 \%)$. Among the surveyed companies there were none in the publishing/advertising/media industry $(0 \%)$.

The results presented in this paper are a fragment of a bigger survey conducted among employees at various managerial echelons in organisations where informatic projects are undertaken.

The enterprises surveyed indicated that they were running IT projects to satisfy different needs: on their own and for own needs $-75 \%$ of answers given, for the enterprise's clients $-53 \%$, for own needs with external suppliers involved $-78 \%$, in consortia $11 \%$. The results show that organisations undertake project activities, but the smallest number thereof runs projects in consortia with different business entities. Consortia are most often established for very big or risky investments. The purpose of setting up a consortium is to temporarily run operations together with a view to carrying out a specific business undertaking whose execution is, due to different determinants, beyond one entity's capabilities.

Another question concerned the assessment of the intensity of the use of IT tools at various stages of project delivery (initiating, planning, executing, controlling and monitoring, and closing). The traditional approach to running projects (stages) was chosen, due to the fact that, as indicated, it is also a characteristic of the agile approach. For the assessment of the intensity of the use of IT tools, a descriptive five grade scale was provided. Presented below are the results of the answers provided by the enterprises surveyed, divided into the consecutive development stages of an informatic project.
The enterprises indicated that informatic tools are applied intensively (33\%) or with medium (31\%) intensity at the stage of initiating of an IT project. Another group of enterprises indicated that at this stage they do not apply IT tools (19\%); $14 \%$ of the organisations surveyed answered that IT tools are used by them very intensively, while 3\% stated that in their case the intensity of the use of such tools is little. Focusing on the satisfactory answers (very intensively, intensively, medium intensively), one can find that the vast majority of enterprises use IT tools at the stage of project initiation (as many as 78\%).

The results are presented in Figure 4.

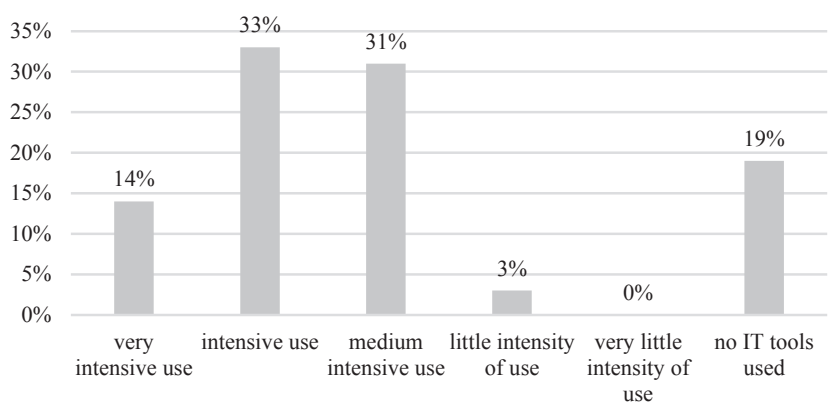

Fig. 4. Assessment of the use of IT tools for initiating an IT project Source: own study based on original survey results.

As many as $42 \%$ of the organisations surveyed indicate that they very intensively apply IT tools at the planning stage of an IT project, while $27 \%$ organisations declare an intensive use of IT tools at this stage. $12 \%$ use IT tools at the planning stage with medium intensity. As many as $19 \%$ of the enterprises surveyed answered that they apply IT tools at the planning stage with very little intensity. Similarly to the previous question, focusing on the satisfactory answers (very intensively, intensively, medium intensively), one can find that the vast majority of enterprises use IT tools at the stage of project planning (as many as $81 \%$ ).

The results are presented in Figure 5.

The next stage of an IT project is its physical execution. As many as $63 \%$ of the enterprises indicated that they use the tools intensively, $34 \%$ use them very intensively, and $3 \%$ - with medium intensity. It can be observed that at the execution stage of IT projects, all of the enterprises $(100 \%)$ which participated in the survey apply IT tools.

The results are presented in Figure 6.

At the stage of controlling and monitoring, IT tools are applied very intensively by $43 \%$ of the enterprises, intensively - by $19 \%$ of them, and medium intensively by $18 \%$. Interestingly, at this stage, $19 \%$ of the enterprises declared that they use 


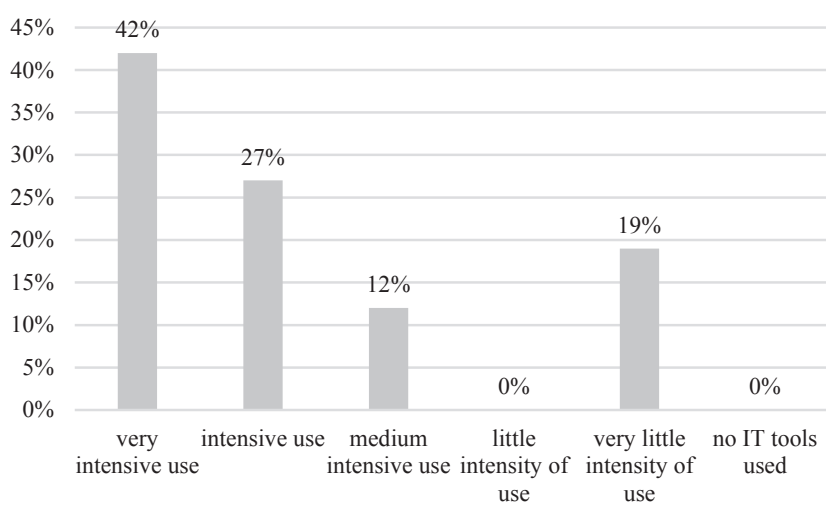

Fig. 5. Assessment of the use of IT tools for planning an IT project Source: own study based on original survey results.

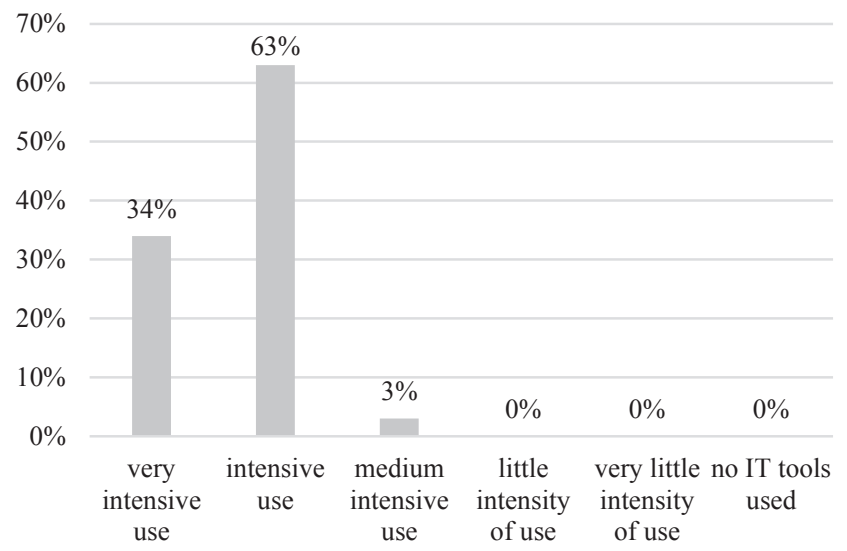

Fig. 6. Assessment of the use of IT tools for executing an IT project

Source: own study based on original survey results.

IT tools with very little intensity, while $1 \%$ do not apply them at all. This is a surprising fact, as most IT tools have modules facilitating the analysis of current progress/deficiencies, which in many cases would make it easier to correct actions taken over the course of an IT project. Therefore, it may be a suggestion for organisations which develop such solutions that they should pay attention to this stage in their clients' initiatives. Focusing on the satisfactory answers (very intensively, intensively, medium intensively), one can find that the vast majority of enterprises use IT tools at the stage of project control and monitoring (as many as $80 \%)$.

The results are presented in Figure 7.

The stage of project closing is diverse in terms of answers concerning the use of IT tools. These are applied very intensively in $21 \%$ of the enterprises, intensively in $25 \%$ of them, and medium intensively in $19 \%$. $26 \%$ of the enterprises indicated little or even very little intensity of the use of IT tools. $9 \%$ of the organisations surveyed answered that they do not use
IT tools at all. Focusing on the satisfactory answers (very intensively, intensively, medium intensively), one can find that the vast majority of enterprises use IT tools at the stage of project closing (as many as $65 \%)$.

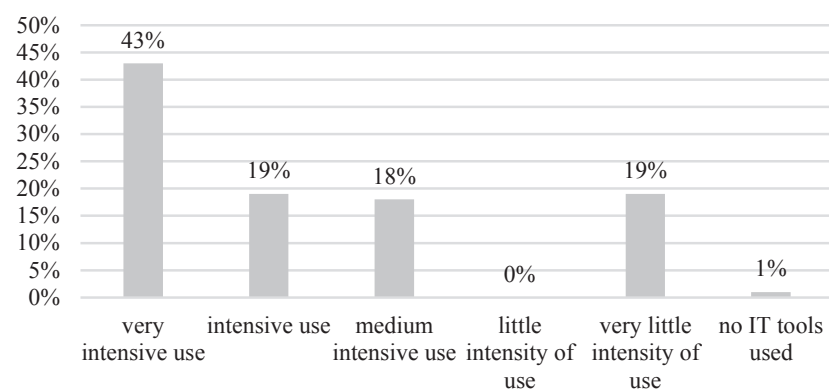

Fig. 7. Assessment of the use of IT tools for controlling and monitoring an IT project

Source: own study based on original survey results.

The results are presented in Figure 8.

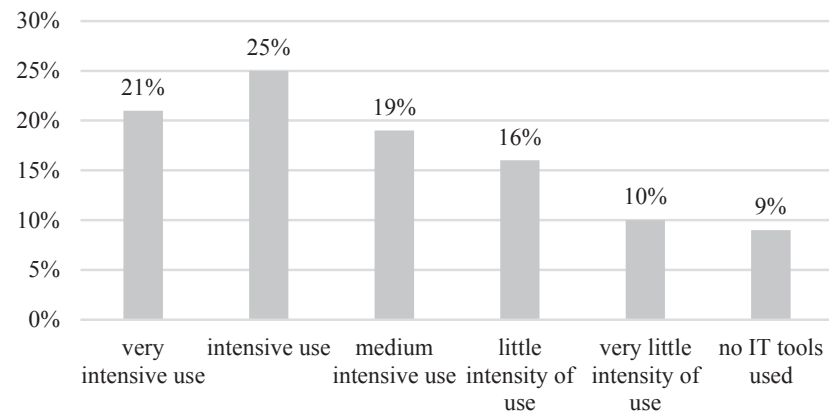

Fig. 8. Assessment of the use of IT tools for closing an IT project Source: own study based on original survey results.

Table 1 presents the grouped ratings of respondents to the use of IT tools at each stage of the project.

Table 1. Briefing about the rating of the use of IT tools in an IT project

\begin{tabular}{|c|c|c|c|c|}
\hline & \multirow{2}{*}{$\begin{array}{c}\text { very } \\
\text { intensely, } \\
\text { intensively }\end{array}$} & \multirow[t]{2}{*}{$\begin{array}{c}\text { moderately } \\
\text { intensive }\end{array}$} & $\begin{array}{c}\text { less intense, } \\
\text { very little }\end{array}$ & \multirow{2}{*}{$\begin{array}{l}\text { we do } \\
\text { not use } \\
\text { IT tools }\end{array}$} \\
\hline & & & intensively & \\
\hline initiating & $47 \%$ & $31 \%$ & $3 \%$ & $19 \%$ \\
\hline planning & $69 \%$ & $12 \%$ & $19 \%$ & $0 \%$ \\
\hline $\begin{array}{l}\text { implemen- } \\
\text { tation }\end{array}$ & $97 \%$ & $3 \%$ & $0 \%$ & $0 \%$ \\
\hline $\begin{array}{l}\text { control and } \\
\text { monitoring }\end{array}$ & $62 \%$ & $18 \%$ & $19 \%$ & $1 \%$ \\
\hline closing & $46 \%$ & $19 \%$ & $26 \%$ & $9 \%$ \\
\hline
\end{tabular}

Source: own study based on original survey results. 
Companies most intensely use the IT tools at the stage of implementation (97\%), followed by planning $(69 \%)$, control and monitoring (62\%). As one can see, companies are paying a lot of attention to streamlining the implementation process, but they are less optimistic about the IT tools for closing projects (26\%), planning (19\%), control and monitoring $(19 \%)$.

The results indicate that companies do not use the available IT tools for IT projects. The closing phase of the project is extremely important because the knowledge gained from the whole project should be recorded. It allows, among other things, to draw conclusions and tips for future projects and thereby reduce or eliminate errors resulting from previous projects. In the future, this can help to increase the effectiveness of projects in terms of their success. Proper planning, control and monitoring are the next important steps in which the use of IT tools increases the effectiveness of these steps and contributes to the success of the entire task. The IT tools that are available on the market make it easy to carry out project tasks and to allocate resources to the project, using the right tools to achieve the target within a specified time frame, at cost and quality.

The next question inquired about the areas of the enterprises' use of IT tools for managing IT projects (using a fixed five grade scale). The results were expected to contribute to the identification of areas where the enterprises most often apply IT tools when developing their IT projects.

The results are presented in Table 2.

Dividing responses into three groups:

1) very important and important,

2) partly important,

3) of little importance and unimportant, it can be stated that respondents highly value the use of tools in the area of resource management (87\%), task reporting and management $(82 \%)$, workflow systems (81\%) and group work $(80 \%)$. These are areas where the support of activities related to the efficiency of IT projects implementation is very important in the examined companies. Therefore, it may be a suggestion for other companies to draw attention to the operation or the implementation of IT tools to the identified areas while implementing their activities.

The areas of least used tools (not important, not important) were reporting and analysis (37\%), portfolio management (24\%), planning, scheduling $(12 \%)$. These areas from the point of view of the relevance of information provided to enterprises are extremely important, however, the importance of using IT tools according to respondents was low. This can be a suggestion for IT companies developing their solutions to this area. It seems that the areas indicated are important but currently not properly supported by IT tools. A more detailed analysis of the problem would be needed (a topic to be taken up in further studies).

The authors also focused on the evaluation of respondents regarding the significance of the use of information tools supporting IT project management in the survey (list of 28 tools). The tools were selected from those available on the market without dividing them into paid and free tools. Many of them are available in both versions. The responses are presented as a percentage of the tool in a specific category of response (very important, important, partly important, of little importance, unimportant, we do not use the indicated). Among the surveyed companies, the most important (very important, important) evaluation was the Microsoft tools: MS Project (25\%), MS SharePoint $(20 \%)$, Jira (17\%), MS Project Server (16\%), Solo (16\%, Asana (15\%), Assembla (10\%), Kanban Tool (11\%), Zoho (11\%).

Weakest in the assessment of the use by companies are: Clarizen, Freedcamp, LiquidPlanner, Project

Table 2. Breakdown of assessments of the importance of areas of the use of IT tools for IT projects

\begin{tabular}{|l|c|c|c|c|c|}
\cline { 2 - 5 } \multicolumn{1}{c|}{} & $\begin{array}{c}\text { very } \\
\text { important }\end{array}$ & important & $\begin{array}{c}\text { partly } \\
\text { important }\end{array}$ & $\begin{array}{c}\text { of little } \\
\text { importance }\end{array}$ & unimportant \\
\hline group work & $43 \%$ & $37 \%$ & $12 \%$ & $8 \%$ & $0 \%$ \\
\hline task management and reporting (ticket systems) & $52 \%$ & $30 \%$ & $18 \%$ & $0 \%$ & $0 \%$ \\
\hline planning, scheduling & $18 \%$ & $17 \%$ & $53 \%$ & $12 \%$ & $0 \%$ \\
\hline project portfolio management & $19 \%$ & $45 \%$ & $12 \%$ & $19 \%$ & $5 \%$ \\
\hline resource management & $28 \%$ & $59 \%$ & $4 \%$ & $9 \%$ & $0 \%$ \\
\hline document management (DMS) & $16 \%$ & $30 \%$ & $54 \%$ & $0 \%$ & $0 \%$ \\
\hline workflow systems & $40 \%$ & $41 \%$ & $10 \%$ & $9 \%$ & $0 \%$ \\
\hline reporting and analysis & $27 \%$ & $2 \%$ & $34 \%$ & $12 \%$ & $25 \%$ \\
\hline
\end{tabular}

Source: own study based on original survey results. 
Bubble, Projecturf, Wrike. Although they are the world's leading IT tools for managing IT projects, companies have not indicated their use. This is due, for example, to the lack of knowledge of the tool, the lack of willingness, or the need to implement a new tool, since the company is satisfied with the functionality of the solutions currently being used.

\section{Conclusion}

The research conducted proves that enterprises are highly aware of the use of IT tools for the purposes of IT projects. This paper shows the important role of a skilful usage of IT tools for each stage of the project, as each of them is very important and influences the success of the whole project. It is important that companies executing IT projects that want to be competitive in the market use information technology tools.

It is vital that enterprises delivering solutions dedicated to informatic projects focus on the area related to the stage of reporting and analysis, planning and scheduling, and portfolio management. These stages are poorly supported by dedicated IT tools in the opinion of the companies conducting the projects. This may be due to a lack of awareness of the relevance of information that can be obtained at these stages.

IT tools have been highly appreciated for enabling tasks in the area of resource management, task reporting and management, workflow systems and groupware.

Enterprises providing IT tools for companies performing IT projects should develop solutions that enable more efficient implementation of all stages and areas (especially in those underperforming). They should make greater efforts to create tools that are dedicated to the reporting and analysis, planning and scheduling areas, as these are very important milestones, but the intensity of the use of IT tools in these areas is insignificant. This may be due to a variety of factors, such as the price of these tools, their popularity, or the difficulty (s) of their operation, or the lack of knowledge about the usefulness of the information that users can achieve using the tools.

By analyzing the ratings of respondents, Microsoft is the unquestioned leader in providing software for everyday use for businesses of all sizes and industries. Over the years, Microsoft has also developed a powerful platform for processing, analyzing, and managing data.

Importantly, it is not a product targeted at a single, narrow audience, its implementation has no established templates, allowing for great flexibility and adaptability to the requirements of a particular project. Flexibility and the tools that make up the platform make Microsoft solutions (including project management) highly ranked in various rankings (as confirmed in the study).

According to the Welcoming Innovation Revolution report, developed by the GE Global Innovation Barometer 2016, as many as $83 \%$ of Polish enterprises voice an interest in new technologies [Poland 2016] and the willingness to use them. As far as Polish managers are concerned, $57 \%$ of them see the impact of digitalisation on the development of new sources of their business operation's income, while $67 \%$ claim that data analysis tools will be a priority in the field of discovering new business growth areas [Jamrogiewicz 2016].

According to the survey, the leading companies focus on the use of IT tools primarily at the stage of project implementation, but underestimated the importance of the remaining phases. This may be because they think it is important to perform scheduled tasks without changing or reacting to emerging risks. This issue will be analyzed in subsequent studies, since the optimization of the processes based on new technologies is unavoidable.

It is important that enterprises implement technologies to attain a competitive advantage in various areas, e.g. document management, quicker drawing up businesses proposals, more effective online promotion, appropriate reactions to clients' new enquiries, and more efficient communication. Depending on the available financial resources and time, there are IT solutions on the market in the shape of services which do not require big investment outlays, sophisticated knowledge, or even more so, a time-consuming technology implementation process. Applying well-known and friendly applications, enterprises running IT projects can much more efficiently perform their tasks and attain their goals and much more effectively create value for the end client.

\section{Bibliography}

Bernroider E. W., Ivanov M., 2011, IT project management control and the Control Objectives for IT and related Technology (CobiT) framework. International Journal of Project Management, 29(3).

Cleland D.L., Ireland L.R., 2006, Project Management, McGraw-Hill Professional.

Computerworld, 2015, Wykorzystanie systemów BI w przedsiębiorstwach $i$ instytucjach publicznych szanse, zagrożenia, trendy, IDG Poland, Warszawa.

Demeyer R., Van Assche M., Langevine L., Vanhoof W., 2010, Declarative workflows to efficiently manage flexible and advanced business processes, Proceedings of the 12th interna- 
tional ACM SIGPLAN Symposium on principles and practice of declarative programming, ACM.

Duncan W.R., 1996, A Guide to the Project Management Body of Knowledge, U.S.A. Project Management Institute.

https://news.microsoft.com/pl-pl/2016/07/19/msp-dostrzega-korzysci-ale-nadal-zwleka-z cyfrowa-zmiana/\#sm.000014smnphy9ye60pjaky7kdisru (10.10.2016).

IBM, 2016, www.ibm.com/software/data/bigdata (10.10.2016).

Jamrogiewicz P., 2016, MŚP dostrzega korzyści, ale nadal zwleka z cyfrowa zmiana,

Kerzner H., 2013, Project Management: a Systems Approach to Planning, Scheduling, and Controlling, John Wiley \& Sons.

Koźmiński A., Piotrowski W., 2013, Zarządzanie. Teoria i prakty$k a$, Wydawnictwo Naukowe PWN, Warsaw.

Lock D., 2009, Podstawy zarzadzania projektami, Polskie Wydawnictwo Ekonomiczne, Warsaw.

Meredith J.R., Mantel Jr S.J., 2011, Project Management: a Managerial Approach, John Wiley \& Sons.

Pawlak M., 2006, Zarzadzanie projektami, Wydawnictwo Naukowe PWN, Warsaw.

Philips J., 2011, Zarządzanie projektami IT, Helion, Gliwice.

PMI (Project Management Institute), 2013, A Guide to the Project Management Body of Knowledge (Pmbok Guide) - 5th Edition, Ingram International Inc., La Vergne, Tennessee.
Pondel M., Pondel J., 2016, Big Data Solutions in Cloud Environment, Federated Conference on Computer Science and Information Systems (FedCSIS), Gdańsk, Poland.

PRINCE2, 2006, Skuteczne zarządzanie projektami, OGC, London.

Rawski P., 2016, Zarzadzanie projektami i zasobami, http://informatykawfirmie.pl/systemy-informatyczne/projekty-i-zasoby-ludzkie/58-10-najlepszych-darmowych-systemow-doobslugi-zgloszen (10.11.2016).

Schmidt M., 1998, Building workflow business objects, Business Object Design and Implementation II, Springer, London.

Schwalbe K., 2015, Information Technology Project Management, Cengage Learning.

Szyjewski, Z., 2004, Metodyki zarzadzania projektami informatycznymi, Placet, Warsaw.

Trocki M., Grucza B., Ogonek K., 2003, Zarządzanie projektami, PWE, Warsaw.

Wiki, 2016, Comparison of Project Management Software, https://en.wikipedia.org/wiki/Comparison_of_project_management_software (10.11.2016).

\section{ETAPY I OBSZARY WYKORZYSTANIA NARZĘDZI INFORMATYCZNYCH WSPOMAGAJĄCYCH ZARZĄDZANIE PROJEKTAMI INFORMATYCZNYMI}

Streszczenie: Projekty IT wymagają wykorzystania nowych rozwiązań, zaawansowanych technik analizy. Są skomplikowane, podczas ich realizacji generowane są duże ilości danych, informacji o różnej formie, poziomie szczegółowości. Przedstawiono rozważania dotyczące projektów informatycznych, wskazano etapy oraz obszary realizacji projektów oraz klasy narzędzi informatycznych wspierających realizację. Celem artykułu jest ocena poziomu wykorzystania narzędzi IT przez zaawansowane przedsiębiorstwa na poszczególnych etapach realizacji projektów IT (ich rekomendacja) oraz ocena intensywności wykorzystania narzędzi w poszczególnych obszarach. Przedstawione zostały wyniki badań, będących wskazówką dla przedsiębiorstw tworzących narzędzia informatyczne do usprawniania prowadzenia projektów informatycznych. Wykorzystano badania literaturowe oraz analizy empiryczne.

Słowa kluczowe: projekt informatyczny, etapy projektu, narzędzia informatyczne, obszary zarządzania. 